TranscUlturAl vol. 1, (4) 2011, 31-46.

http://ejournals.library.ualberta.ca/index.php/TC

\title{
The City as Dialectic: Andrei Bely's Creative Consciousness, its Nietzschean Influence, and the Urban Centre in Petersburg
}

\author{
Sandra Joy Russell \\ Central Michigan University
}

In Petersburg (1916), Andrei Bely uses the space of St. Petersburg to examine, and ultimately to reconfigure, the persistent question of identity within the Russian psyche. Bely's awareness of the city's national significance allows him to work within the symbolic, drawing from various disciplines including mythology, philosophy, and mathematics. The novel's narrative timeframe spans from September 30 to October 9, 1905-just days before the onset of the Russian Revolution. Bely intentionally uses this historical framework of time and space to address Russia's impending political, social, and even psychological upheaval. His fundamental concern lies both in Russia's geographic positioning between Western and Eastern Europe and in the social and cultural consequences of conflicting ideologies. As Robert A. Maguire and John E. Malmstad suggest in the novel's introduction, the city's geographic positioning contributes to its greater cultural uncertainty; it pits the Neo-Kantian reason, structure, and order of the "west" against the alleged irrational, impalpable, and intuitive nature of the "east" (Bely viii). In the novel, in terms of geographical significance, St. Petersburg exists as dialectic for the symbolic relationship between the city's geometric spaces and its more general positioning within the axis of time and space. Bely's calculated and mathematical re-creation of the city through the text allows it to operate as a public space for the articulation of Russia's political and cultural anxiety. The novel itself exists as a symbol of the city: both are interchangeable, developmental centres from which the modern can be examined and (importantly for Russia) understood.

Bely's Nietzschean influence is evident throughout Petersburg as both the structure and the actions of its inhabitants are circular. According to Maguire and Malmstad, Nietzsche became a heroic philosophical figure for Russians at the beginning of the twentieth century (101). For Bely this influence was of paramount importance, as Thus Spoke Zarathustra became his "constant companion" throughout his intellectual development. This was largely due to Nietzsche's notion that "philosophy is really psychology," and likewise, Bely's connection with his work was, above all, creative (Maguire and Malmstad 101-2). The 
TranscUlturAl vol. 1, (4) 2011, 31-46.

http://ejournals.library.ualberta.ca/index.php/TC

essential parallelism between Bely's work and Nietzschean thought lies in his interpretation. Given Bely's tendency to privilege creativity, his interpretation unsurprisingly relies heavily on its relationship to the creative rather than the philosophical. This is seen extensively in his fascination with Nietzsche's notion of eternal return. Maguire and Malmstad note that while Bely's use and understanding of this concept fluctuated over the years, he understood Nietzsche's idea of "returning" as being a creative action, describing the circularity of every artistic, philosophical, and literary endeavor (103). Ultimately, this interpretation ignited Bely's examination and creation of Petersburg, as within this context, the symbolic rests within the act of creation. Regarding Bely's employment of Nietzsche, Carol Anschuetz suggests that, "Petersburg simultaneously interprets Nietzsche's philosophy in terms of Russian literature and represents Russian literature in terms of Nietzsche's philosophy" (125). By placing him ideologically within the centre and structure of St. Petersburg, Bely allows Nietzsche, and thus Western ideals, to become part of the Russian philosophical landscape. This aspect does not fundamentally change Russian identity, but rather allows it to reconsider itself in its synthesis of Eastern and Western Europe, facilitating Bely's "diagnosis of modern culture" (Maguire and Malmstad 102).

Bely's organization of the novel begins and ends symbolically, as is apparent in how he structures the narrator's language. The novel's confused and fragmented narration initiates a sense of disorder. According to Maguire and Malmstad, the narrator's bumbling and clumsy introduction in the Prologue seeks to mimic the beginning of Imperial proclamations, which list all of the Emperor's official titles. The narrator uses this space to address and invoke a particularly Russian audience, as he states, "Your Excellencies, Your Worships, Your Honors, and Citizens!” (Bely 1). Bely's boorish imitation suggests his distrust of political and social formality (Bely 295). He continues by characterizing Petersburg as a particular kind of investigation and does so by inquiry, asking, "What is this Russian Empire of ours?" (Bely 1). The scrutiny of Russia's placement within the context of space and time is important to this structure. The phrasing of this question considers public responsibility, and allows the novel to operate as an investigation of what St. Petersburg is and, ultimately, how it ought to be understood. The narrator shifts to the geographic by attempting to answer his own question: "This Russian Empire of ours is a geographical entity, which means: part of a certain planet" (Bely 1). This speaks not only to the geographic positioning of Russia, but also of St. Petersburg itself. The continued rambling 
TranscUlturAl vol. 1, (4) 2011, 31-46.

http://ejournals.library.ualberta.ca/index.php/TC

throughout the prologue establishes a vague and inarticulate relationship between the reader and the narrator.

Vladimir E. Alexandrov suggests that Bely's imprecision, and sometimes even unintelligibility, demands that the reader "participate actively in the work-much more than normally-in order to infer the necessary continuations and conclusions" (101). This ambiguity engages the audience in a philosophical dialogue with the text, as well as with the space of the city. Bely's pattern of confused and delineated linguistic structuring is consistent throughout the novel due to the narrator's vague and clumsy picture of the space of Petersburg and the behavior within it. The narrative framing of the city is both fragmented and unreliable and the reader is unsure whether or not to trust it. Bely therefore indirectly encourages the reader to construct her own understanding of the city and its inhabitants. In his description of Apollon's position, he states, “Apollon Apollonovich was head of a Government Institution. Oh, uhhh, what was its name?” (Bely 5). The narrator's speech, as Alexandrov notes, is the antithesis of Apollon's verbal exchanges, which, as the narrator describes, "had to have a goal, plane and straight as a line" (Bely 122). The disparity between character and narrator can be attributed to Bely's "definition of the reality of Russia" (Alexandrov 128); that is, a nation experiencing political and social anxiety on the brink of upheaval rather than a well-organized and structured machine.

Bely's narrative conversation with the reader facilitates his investigation of the modern. This occurs particularly through his structuring of relationships, and especially the language he uses to describe these relationships. Bely uses both space and time when he introduces the reader to Apollon and his son Nikolai. Apollon's existence within these structures allows him to create a dialogue with himself; that is, one that is predictable and "secure." Nikolai, on the other hand, exists and behaves outside of these frameworks, thus establishong an immediate tension. An example of this can be seen in their unsynchronized behaviors described at the very beginning of the novel. During breakfast, the senator asks his valet, "Is Nikolai Apollonovich up yet?" to which he responds, "No indeed, sir, he's not up yet...." (Bely 4). The narrator characterizes this as being typical of their relationship, as "It was precisely half past nine. Every morning the senator inquired about the times of his awakening. And every morning he made a face. Nikolai Apollonovich was the senator's son" (Bely 4). The novel establishes this father-son relationship as lacking continuity, as Apollon lives within the precision of time whereas Nikolai ignores it. Underscoring this disconnect is 
TranscUlturAl vol. 1, (4) 2011, 31-46.

http://ejournals.library.ualberta.ca/index.php/TC

the narrative's linguistic structure and organization, as Bely establishes their unsynchronized behaviors prior to defining the nature of their relationship. The novel's creative motion and its political implications are also evident within this parent-child relationship, and it is through language that Bely constructs Apollon's prioritization of order over connection. The Apollonian and Dionysian components present in Apollon and Nikolai further establish the tension between East and West: neither behaves consistently, both are equally insecure about his beliefs and conventions.

The narrator's lax conversational tone and the text's conoluted and often confusing structure also allow for audience participation in its textual creation, as they provoke reader's skepticism. As Bely centralizes the city, the narrator is decentralized. Peter I. Barta points out that the "narrational function lacks a unique perspective" (22). Perspective is placed in the hands of the reader, who is herself a centre, and whose dialogue with Petersburg is, like the city, expanding outward. This refers to Bely's use of geometry in his discussion of the city as it allows him to approach both it and the novel symbolically. Much of the discussion surrounding Bely's symbolic placement refers to his use of symbols to, as Alexandrov suggests, "express the primacy of creation over cognition" (103). As Bely argues regarding his own philosophical methodology, "one must create life" (Maguire and Malmstad 98), and indeed his narration of the city works toward this sort of creation. This approach to the city emphasizes that all things, including "particles, forces and ions" are the products of a process that is first creative, and second cognitive (Alexandrov 103). Mathematically, these three forces exist within the city's structural as well as human components, which move and direct its outward expansion.

In "The City of Russian Modernist Fiction," Donald Fanger describes St. Petersburg as the "epicentre of the shocks that were transforming the cultural landscape of Russia" (469). Within the Russian social-consciousness, the city of St. Petersburg is emblematic of its movement toward the West, and thus stands as a unique centre from which a modern Russia can be examined. Bely's approach to both the city and the novel is rooted in the notion of outward movement and expansion. He articulates this in the last paragraph of the novel's prologue by describing its cartographic placement: "Petersburg not only appears to us, but actually does appear-on maps: in the form of two small circles, one set inside of the other, with a black dot in the centre; and from precisely this mathematical point, which has no dimension, it proclaims forcefully that it exists" (Bely 2). Bely gives the city agency, allowing 
TranscUlturAl vol. 1, (4) 2011, 31-46.

http://ejournals.library.ualberta.ca/index.php/TC

it to speak for itself. Likewise, this positioning of St. Petersburg establishes its role as both a geometric and geographic space. Its movement extends beyond the city's physical structure into the novel itself, as "from here, from this very point swarms and surges the printed book; from this invisible point speeds the official circular" (2). The novel then, like the city, moves outward in the act of creation, establishing itself as an investigation and recreation of what it means to be both Russian and modern. It is through this movement that Bely refers to Nietzsche, as he is continually returning to the creative centre of the city, and likewise, he reexamines and reconfigures a modern Russia. As a cultural nucleus, the textual space of Petersburg projects the modern and also informs and clarifies the movement of the people within the space of the city and ultimately the nation.

The space of St. Petersburg, and particularly its geometric composition, enables and encourages its movement and expansion. For Bely, the city's central public vein for mobility is Nevsky Prospect, the main road through Petersburg which, as he notes, "consists of a space for the circulation of the public.... Nevsky Prospect, like any prospect, is a public prospect, that is: a prospect for the circulation of the public (not of air, for instance)" (2). Such a space, for Bely, allows for the movement and continuity of the city, both linearly (as in the physical structure of Nevsky Prospect) and circularly (for the social movement of the public). The public's movement within this space contributes to the city's expansion. Barta discusses this in relation to the city's "walkers" who lose their individual identity as they move through the space of Petersburg. Bely's presentation of Nevsky Prospect describes not so much the road's physical constitution as its spatial positioning. In other words, it is the public movement on the road that defines its presence within the city. He notes, "All the shoulders formed a viscous and slowly flowing sediment...In keeping with the laws of the organic wholeness of the body, [Alexander Ivanovich] followed the shoulder and thus was cast out onto the Nevsky" (Bely 178). Its wholeness is composed many parts as the people moving on it are merely one part of its conceptual machinery.

Bely's placement within modernity, as Anschuetz contends, is tied to his interest in a psychological approach to ethics. This approach is what sets Petersburg apart from nineteenth century Russian writers like Tolstoy, Dostoyevsky, and Gogol. The novel, she argues, is his attempt to reformulate the problem of theodicy that continually plagued the European conscience (Anschuetz 125-6). Even prior to the twentieth century, there were questions concerning how Russian society ought to manage its seemingly inevitable embrace of 
TranscUlturAl vol. 1, (4) 2011, 31-46.

http://ejournals.library.ualberta.ca/index.php/TC

Western values and the consequent upheaval of Russian values. This crisis of values, Anschuetz notes, threatened above all to collapse the structure of the family (126). This structure is seen extensively in Tolstoy and Dostoyevsky; both authors contextualize a system of values by way of family, a cohesive moral centre. In contrast, Bely places Petersburg as the centre and familial components, primarily Apollon and Nikolai, as "movers" within the psychological structure of the city. This, again, relates to his incorporation of Nietzsche, and particularly the Nietzschean notion that religion's repeated misappropriation of "good" and "evil" has resulted in a greater cultural crisis of values, thus requiring a reassessment of what ought to be valued. For Bely and other Symbolists, however, this assessment became an artistic rather than philosophical endeavor. As Fanger suggests, "[t]he Russian writer, whose moral responsibility to the people appeared central through most of the nineteenth century, became in the twentieth an artist: formerly sincere and direct, he was now artful and crafty" (468). This literary shift reflects Russia's and the West's rising secularism and furthers St. Petersburg's placement as a new centre from which Russian identity can be understood psychologically.

In his articulation of the polarity between Eastern and Western values, Bely emphasizes the disjunction in the relationships of Petersburg's inhabitants, which in turn speaks to disorder and anxiety on a cultural level. The disparity between Apollon and Nikolai Ableukhov is symptomatic of Russia's escalating political and social tension at the beginning of the twentieth century. Bely characterizes East and West through this father-son paring: the powerful, yet alienated, rational, intellectual senator; and the confused, impressionable, emotionally-driven son. His use of binaries draws upon conflicting cultural notions of value and questions what ought to be valued with respect to Russian culture and power. Bely's choice to position this relationship within the space of Petersburg symbolizes Russia's larger positioning in the modernizing world. These problematic and often fragmented familial relationships are indicative of fragmentation on a national level, as "the old values were no longer adequate to the new realities" (Bely xii). Likewise, Bely's use of language throughout the novel reflects a sense of anxiety and impending catastrophe, and his use of elapsing time (as seen in the ticking bomb) demonstrates the unstoppable and inevitable progress into the modern. Bely again positions Petersburg as a precise "mathematical point" (2) from which a shifting and modernizing Russian identity can be assessed and reevaluated.

Bely's attempt to position St. Petersburg as a symbolic centre of Russian identity is 
TranscUlturAl vol. 1, (4) 2011, 31-46.

http://ejournals.library.ualberta.ca/index.php/TC

evident in his artistic approach to the space of the city. His conscious and liberal use of geometric space is directly connected to his academic and philosophical upbringing. Ithe intellectual intellectual circles in which Bely moved were critical to his development as a Symbolist. Solomon Volkov notes that Russia's symbolist movement, which began at the end of the nineteenth century, was its "first fledging modernist movement," seeking out a "new impressionability" learned from "Western masters" (127). Bely's work as a Symbolist was, according to Steven Cassedy, focused on the act of creation (289). In "Andrei Bely and the Argonauts' Mythmaking," Alexander Lavrov discusses Bely's role in Russia's Symbolist culture, and particularly his relationship with Moscow's Argonaut circle, a community of thinkers who initiated an attempt to break away from the "ideas, tastes, illusions, and beliefs" of the previous century (Lavrov 84). This movement, however, was not strictly literary. It encompassed a wide-range of intellectual endeavors, all concerned with the act of creation and seeking to "mythicize daily life" (Lavrov 83-4). Lavrov mentions that the Argonaut circle "underlined by its very existence that artistic system's striving to become a life-creating method" as they "declared 'life-creation' to be their basic primary task" (83). This notion of "life-creation" correlates with Bely's textual approach. His writing of the city is itself an act of creation, allowing him to address Russia's cultural afflictions by way of St. Petersburg's recreation, and thus its reconfiguration. Lavrov continues by describing the Argonaut's unifying themes found throughout their work, particularly the conviction that "talent for writing" and "talent for living" should be weighted equally. This break from normativity and attempt to create "newness," as embraced by Russia's Argonauts, aligns Russia with European modernism. In applying these ideas to the literary context, Bely typifies this creative and self-conscious movement in Petersburg, not only for Russia but also on a global scale. What exists within the space of the city is its creation by way of the symbolic: the interchangeability of linear and circular geometric movements within the city, both reflecting the structures of space and time.

Bely's participation in Moscow's Argonaut circle set up for him the world of the symbolic, and thus its geometric implementation within the space of Petersburg. In The Culture of Time and Space, Stephen Kern explains the spatial with respect to a post-Enlightenment concern with structure, as initiated by Kant. This structure broke away from Euclidian geometry which points to its "absolute space," which is "always similar and immutable" (qtd. in Kern 132). According to James West, Bely devoted approximately three years (1906-1909) 
TranscUlturAl vol. 1, (4) 2011, 31-46.

http://ejournals.library.ualberta.ca/index.php/TC

to the study of Kant. In applying this study to his extensive work with Nietzsche, he "attempted to synthesize Neo-Kantian and theosophical ideas," and, having done so, he felt he could put forward "some advance on the position of the Neo-Kantians" (West 98-9). Bely's structuring of the novel attempts to reframe Kant's Western thought within the city's symbolic structure. In doing so, Bely emphasizes the tension between East and West in his placement of Kant within the context and space of St. Petersburg. For example, the bust of Kant in Nikolai's room exists alongside disorder and asymmetry. Moreover, Nikolai's behavior within that space does not reflect the order and reason of the West, as "for two years... [he] had not risen before noon" (Bely 27). Kant is a point of misunderstanding between Nikolai and Apollon. When attempting to converse with his father during a meal, Nikolai brings up philosophy, mentioning, "Cohen is a representative of serious neoKantianism;" to which Apollon responds, "You mean Comtianism?" (Bely 79). Their inability to communicate effectively reflects the anxiety underlying the opposing ideological tensions. Bely's desire to synthesize East and West is indicative of the "mathematical point" to which he refers in the Prologue and its attempt to reframe Russian identity is tied to its movement towards modernity.

Regarding the novel's broader theoretical placement within modernism, Anschuetz argues that, as a novel, Petersburg is not so much philosophical as it is philological (140). In other words, Bely's emphasis lies in the symbolic rather than the epistemic. As such, he is not so much concerned with objective truth or reality as he is with reassessing Russian identity. Because symbolism is threaded throughout the novel, both Bely's philological approach and his treatment of space is primarily geometric. Maguire and Malmstad discuss this in relation to the way in which Bely reads the world as both circular and linear: two presumably different, yet "ultimately identical forms" (98). Both the novel and the city are created to exist spatially between East and West. The novel acts as a kind of map, denoting the progress of civilization, particularly Russian civilization.

The geopolitical role of the novel is to address the particular questions of modernity and Russia's experience as symptomized by uncertainty, anxiety, revolution, and catastrophe. Ada Steinberg argues, "If in Pushkin, St. Petersburg is the second capital of Russia, the stage for a calamity with tragic consequences for one hero, in Bely, Petersburg is the centre of the universe, the spring-board for an inevitable cosmic catastrophe threatening to destroy the whole human race" (524). Here, Steinberg is referring to Aleksandr Pushkin's poem "The 
TranscUlturAl vol. 1, (4) 2011, 31-46.

http://ejournals.library.ualberta.ca/index.php/TC

Bronze Horseman” (1833) that defined St. Petersburg's political importance for Russia's Golden Era. Pushkin's influence on Bely is evident throughout the novel as his stanzas act as thematic epigraphs for each chapter. Steinberg's notion of universal "cosmic catastrophe" relates to the issue of time and space and reaffirms Petersburg's existence (in the city and novel) as a public and creative space for articulating anxiety both geographically and textually.

According to Pierre Hart, intense anxiety became part of Russian Symbolism, resulting in apocalyptic writings as an attempt to "establish a convincing consonance of historical events...as the necessary complement of past and present" (266). The historical comes into play in relation to looming catastrophe as symbolism attempts to reconfigure and represent history symbolically as a way of building to apocalypse.,Steinberg articulates anxiety in relation to the structure of the city itself within its "climate, buildings, statues, streets" (524), thus the anxiety related to impending catastrophe is not only within the geographic positioning of Petersburg, but also within the geometric structures within the city. The narrator contemplates, "But if Petersburg is not the capital, then there is no Petersburg. It only appears to exist" (Bely 2), demonstrating a surreal relationship between the city as a physical structure and the city as a psychological centre. Alexandrov suggests that the dialectic established in the Prologue acts as the narrator's exploration of whether and how Petersburg exists, to which he concludes "what defines it as existent is language" (127). Bely uses the novel to defend his notion that language is itself a creative force. Drawing upon the symbolic nature of language within the space of the city, he establishes his own act of creation through the text.

Apollon's rigid, structured symmetry is indicative of the West as is evident in the narrator's portrayal of the senator's movement within his own private space. Apollon structures it to align with his vision of how Russia's internal political mechanism ought to operate. His external cultivation of a rigid and geometric ecology reflects his desire to orchestrate his own internal machinery. The narrator illustrates this in the first chapter in relation to the senator's response to his heart problems: "Apollon Apollonovich had abandoned himself to his favorite contemplation, cubes, in order to give himself a calm account of what had occurred" (Bely 14). When confronted with fear, and particularly fear of his own mortality, his response is to contemplate structure. In doing do, he is able to organize and control his sense of well-being by way of cognition, which, for Bely, opposes 
TranscUlturAl vol. 1, (4) 2011, 31-46.

http://ejournals.library.ualberta.ca/index.php/TC

the primacy of the creative.

For Bely, St. Petersburg itself is intrinsically geometric and there is therefore a close relationship between Apollon and the city. In 'The 'Apollonian' and the 'Dionysian' in Andrei Bely's Petersburg," Peter Barta describes how the characters' lives are determined and organized by myth. This connects to Bely's creative application of Nietzschean thought, as Barta notes Nietzsche's view that mythmaking allows human beings to "create a world of illusions to block out the terrors of reality" (253). The city, too, is part of this mythology; it can be seen in the inhabitant's interactions with the city's space. Nevsky Prospect, as the narrator points out, has a linear symmetry with a "rectilineal principal" (Bely 11). Likewise, as the senator moves along and within this geometric space, he reaffirms its orderly, and thus "Western," symmetry. The intersection of St. Petersburg's prospects participates in the city's creative expansion, as the narrator continues, "[the prospects] should expand into the abysses of the universe in planes of squares and cubes" (Bely 11). However, as Barta points out, the city also has a "Dionysian" side, that "lies off the well-lit boulevards, in the little swamp-infested passages of Vasilyev Island" where the workers live (254). This chaotic space is not part of Apollon's frame of reference because he "[does] not like the islands: the population there [is] industrial and coarse" (Bely 11). The islands are physically asymmetrical, incongruent with his love of geometry, and, for him, a space of discomfort and unease.

Bely's portrayal of Apollon's political stature and behavior is rooted in geometry as his affinity for an orderly and rigid configuration of his environment permeates his connection (or lack thereof) with others. This structuring works to alienate him not only from his son but also from the citizens of Petersburg-those with whom he as a senator ought to be connected- and he is shown moving in isolation through the public space of the city. In this case, it occurs on the Nevsky Prospect, which Bely emphasizes as being the city's centre for the public's circulation. As he makes his way down the Prospect, the narrator observes how "Apollon Apollonovich Ableukhov [is] gently rocking on the satin seat cushions. He [is] cut off from the scum of the streets by four perpendicular walls. Thus he [is] isolated from the people" (Bely 10). This places him not only within the precision of the carriage's square geometric structure but also within a space of luxury, further revealing his segregation from the "common." This placement in turn isolates him from city's structures, inhabitants, and even its commercial and economic movements, emphasizing the irony of his role as a public representative. His progression through the city and his relationship with 
TranscUlturAl vol. 1, (4) 2011, 31-46.

http://ejournals.library.ualberta.ca/index.php/TC

the city is thus ineffectual, as "we never really see him act. Instead we "see" his thoughts, hear his words, and are told about his endless dictation of directives, all of which have no effect on the world that is crumbling around him" (Maguire and Malmstad 112). In this sense, the senator is incapable of creation and prefers to "lapse into unthinking contemplation of pyramids, triangles, parallelepipeds, cubes, and trapezoids" (Bely 11). For Bely, the senator's behavior works against the creative as the structures already exist within the city. It is for this reason that Apollon's contemplation is "unthinking," as the structures themselves are already part of his consciousness.

Importantly for Petersburg in terms of Bely's symbolic use of Western mythology, the senator and Nikolai both possess Apollonian and Dionysian characteristics. Apollon's green ears, according to Barta, suggest the Dionysian, as green relates to the natural world, which is often unstructured and chaotic (257). There is also a disparity between his public and private lives: in public, his world is structured and orderly while at home, his family life is confused and chaotic (Barta 257). Nikolai expresses a desire to be rational and orderly and chooses to study Western philosophy at university. Moreover, although he is fascinated with Kant's Categorical Imperative, ironically, he allows himself to be persuaded by a radical leftist group to commit patricide. This paring, for Bely, synthesizes West and East within the structure and space of Petersburg. Both the senator and his son are seen working within the context of eternal return; both continually integrate West and East into their movements through and within the city. Their individual movements are acts of creation, sustaining the city's mathematical centre, as it is through the "surging and swarming" that it forcefully proclaims its existence (Bely 2).

The narrator exposes Nikolai's vulnerability through the interactions between father and son, and specifically in the polarity between their behaviors. While Apollon loves symmetry, which is symptomatic of the West, Nikolai operates and exists on the threshold between East and West. This is depicted through Nikolai's love for Kant; however, as Maguire and Malmstad point out, it is offset by Nikolai's very existence, as his conception was the result of Apollon's rape of his wife, Sophia Petronova (Bely xiv). The thread of his life has been repeatedly tied to "sin" and, as Alexandrov notes, "Nikolai himself [has] become a 'composite of disgust, fright, and lechery"' (135), all of which are more associated with the East. The narrator also describes Nikolai's academic devotion to philosophy and his attraction and fascination to the Far East, particularly his interest in Buddhism. For him, 
TranscUlturAl vol. 1, (4) 2011, 31-46.

http://ejournals.library.ualberta.ca/index.php/TC

"Buddhism [has] surpassed all religions in two respects: in the psychological—it taught love for all living creatures; in the theoretical - its logic had been developed by Tibetan lamas" (Bely 164). Nikolai's understanding of Buddhism expresses the tension between the affective and the logical. Like Bely himself, Nikolai is seeking out the symbolic synthesis of the two within an urban context, and he finds himself drawn to the East and attempts to implement it within his understanding of Western philosophy.

Nikolai's movement through the space and time of Petersburg is his attempt to return to a centre. If the city itself, as Bely claims, is a mathematical point expanding outward, Nikolai is working through the symbolic in hope of finding its location. Much of the novel points to Nikolai's childhood as being this centre, and the narrator mentions that he "[yearns] to return to his real home: the nursery" (Bely 220). In "The Eternal Return: Andrej Belyj's Kotik Letaev," Samuel Cioran suggests that much of Bely's writing reflects his own traumatic childhood and expresses his personal desire to return to and reconfigure his past (25). This characterizes Bely's implementation of eternal return within the novel. Nikolai repeatedly returns emotionally to this childhood centre, yet he understands that a physical return cannot conceivably be.

Nikolai's need to return to a centre and his search for an eternal and central "symbol" to which he can return are also physical, as, like the city, the body functions as an invisible centre. In the moment following Nikolai's activation of the bomb, the narrator describes how having been "deprived of his body, he nonetheless [fells] his body: the invisible centre, which had formerly been consciousness...Logic had turned into bones, and syllogisms were wrapped all around like sinews. The contents of logic were now covered with flesh" (Bely 168). He synthesizes West and East when he engages the bomb that has precisely twenty-four hours before it will explode. His philosophical understanding of his action then shifts and he is not only able to contextualize the symbolic, but the symbolic also becomes woven into his father's physical presence. Apollon's fondness for structure and his representation as "Western," is synthesized for Nikolai with the Dionysian "flesh." In this moment of anxiety his father becomes human, and the full effect of Nikolai's impending actions is realized. Jacob Emery argues that the novel is set up to grapple with the issue of kinship and even the "basic conundrum that parent and child are at once the same person, in the same flesh, yet somehow horribly, inexplicably different" (78). For Nikolai, this epiphany evokes the realization that he is biologically, and thus creatively, connected to his father 
TranscUlturAl vol. 1, (4) 2011, 31-46.

http://ejournals.library.ualberta.ca/index.php/TC

through "bone," "sinews," and "flesh.” By aligning Apollon's physical parts with reason ("consciousness," "logic," and "syllogisms"), he is able to identify these qualities within himself, creating an unforeseen connection with his fathe; by destroying his father physically, he would be working against creativity and and the source of his own creation.

Throughout the novel, the father-son relationship exists within a space of tension and anxiety, primarily due to Nikolai's conflicting sense of duty. On the one hand, he feels loyalty to his political responsibility of placing a bomb in his father's room; on the other hand, he is afraid of becoming "a base villain" (Bely 229). It is the sound of the bomb's ticking that jars his understanding of the gravity of his impending action and its moral consequences. The moment the bomb begins to tick, the narrator describes its literal, physical presence in terms of a metaphorical presence of a "bomb" within Nikolai: "Nikolai Apollonovich understood that he himself was a bomb. And he burst with a boom" (Bely 168, emphasis added). Bely draws upon the psychological to illuminate the ethical, as he addresses his understanding of its presence. Nikolai becomes the bomb: a chaotic, explosive centre that, when set off expands outward, like the city. Yet unlike the city, the bomb destroys rather than creates and works against the centre to which Nikolai desperately attempts to return. His anxiety is a product of his awareness of the bomb's anti-creation and its ability to decentralize.

For Bely, the modern is essentialized by way of the symbolic. Through his deliberate use of St. Petersburg as both the symbolic and actual nucleus for a post-Enlightenment Russia, he reaffirms the city's importance within the national psyche. This in turn evokes a greater public awareness of its importance for the West. For him, St. Petersburg's existence as a creative and expanding centre further works to recreate and authenticate what it means to be both modern and Russian. Bely uses the novel to reflect this movement as the roads, buildings, and people of Petersburg and their eternally circular, and linear, movements continue the city's outward expansion. Bely's use of symbols throughout Petersburg works to reassess Russia's persistent issue of identity partly due to its geographic positioning that contributes to its bipolar ideological positioning. His synthesis of West and East by way of the symbolic speaks to the anxiety of modernity and affirms the city's own disjointed unity. For Bely, Russia is indeed unified; however, it needs to return continually to that precise, mathematical centre that is, for him, the locus-point of culture and creativity. This centre is present in the novel's Epilogue, as Apollon in his old age looks back upon his life through 
TranscUlturAl vol. 1, (4) 2011, 31-46.

http://ejournals.library.ualberta.ca/index.php/TC

his memoirs, which the narrator predicts will be published following his death. Regarding these, he states, "And they have seen the light. They are most witty memoirs: all Russia knows them" (Bely 292). Even in the novel's conclusion, Bely retains this centre. Apollon's symbolic treatment of his own movement through life, like the city, is centralized in the creative and lasting expression of his identity. In writing the memoirs, he is at last successfully returning to his own centre and affirming his own identity. Moreover, he, unifies and repositions Petersburg within Russia's cultural identity, and his memoirs act as the symbol for which he had been searching. In this same sense, Bely is writing his own city, repeatedly returning to its locus. Like Apollon's memoirs, it is this locus of creativity and consciousness that enables him to speak to the greater Russian consciousness. 
TranscUlturAl vol. 1, (4) 2011, 31-46.

http://ejournals.library.ualberta.ca/index.php/TC

\section{REFERENCES}

Alexandrov, Vladimir E. "Petersburg." Andrei Bely: The Major Symbolist Fiction. Ed. Editor's name (s). Cambridge: Harvard UP, 1985. Pages. Print.

Anschuetz, Carol. "Bely's Petersburg and the End of the Russian Novel." The Russian Novel from Pushkin to Pasternak. Ed. Editor's name(s). City: Press, 1983. 125-53. Print.

Barta, Peter I. "Knights and Unicorns: The Walkers of Petersburg." Bely, Joyce, and Döblin. Ed. Editor's name. Gainesville: University of Florida Press, 1996. 19-46. Print.

--. “The 'Apollonian' and the 'Dionysian' in Andrei Bely's Petersburg." Study Slavica 32.1-4 (1986): 253-61. Print.

Bely, Andrei. Petersburg. Trans. Robert A. Maguire and John E. Malmstad.

Bloomington, Indiana: Indiana UP, 1978. Print.

Cassedy, Steven. "Bely's Theory of Symbolism." Andrey Bely: Spirit of Symbolism. Ed. John E. Malmstad. Ithaca: Cornell UP, 1987, 285-312. Print.

Cioran, Samuel. "The Eternal Return: Andrej Belyj's Kotik Letaev." The Slavic and East European Journal 15.1 (1971): 22-37. Print.

Emery, Jacob. "Kinship and Figure in Andrey Bely's Petersburg." PMLA 123.1 (2008): 76-91. Print.

Fanger, Donald. "The City of Russian Modernist Fiction." Modernism 1890-1930. Eds. Malcolm Bradbury and James McFarlane. New York: Penguin, 1983. 467-480. Print.

Hart, Pierre. "On Time and Apocalypse in Petersburg." Modern Fiction Studies 30.2 (1984): 26673. Print.

Kern, Stephen. The Culture of Time and Space. Cambridge: Harvard UP, 1983. Print.

Lavrov, Alexander. "Andrei Bely and the Argonaut's Mythmaking." Creating Life: The Aesthetic Utopia of Russian Modernism. Eds. Irina Paparno and Joan Delaney Grossman. Stanford: Stanford UP, 1994, 83-121. Print.

Maguire, Robert A. and John E. Malmstad. "Petersburg." Andrey Bely: Spirit of Symbolism. Ed. John E. Malmstad. Ithaca: Cornell UP, 1987. Print.

Pedersen, Carl. “Unreal Cities East and West; Bely's Petersburg and Dos Passos’s Manhattan Transfer." American Studies in Scandinavia 20.2 (1988): 51-68. Print.

Steinberg, Ada. "Fragmentary 'Prototypes' in Andrey Bely's Novel 'Petersburg.." The Slavonic and East European Review 56.4 (1978): 522-45. Print.

Volkov, Solomon. St. Petersburg: A Cultural History. New York: The Free Press, 1995. 
TranscUlturAl vol. 1, (4) 2011, 31-46.

http://ejournals.library.ualberta.ca/index.php/TC

Print. West, James. "Kant, Kant, Kant: The Neo-Kantian Creative Consciousness in Bely's Peterburg." The European Foundations of Russian Modernism.

Ed. Editor's Name. New York: Mellen P, 1991. 87-135. Print. 